\title{
ERRATA
}

\section{Erratum: Innovative academic startups 2016}

\section{Brady Huggett}

Nat. Biotechnol. 35, 16 (2017); published online 10 January 2017; corrected after print 12 January 2017

In the version of this article initially published, in Table 1, first row of Scientific Founders, William A. Frazier's affiliation was given as Washington State University; the correct affiliation is Washington University, St. Louis. The error has been corrected in the HTML and PDF versions of the article.

\section{Erratum: Multiplex gene editing by CRISPR-Cpf1 using a single crRNA array}

Bernd Zetsche, Matthias Heidenreich, Prarthana Mohanraju, Iana Fedorova, Jeroen Kneppers, Ellen M DeGennaro, Nerges Winblad, Sourav R Choudhury, Omar O Abudayyeh, Jonathan S Gootenberg, Wen Y Wu, David A Scott, Konstantin Severinov, John van der Oost \& Feng Zhang Nat. Biotechnol. 35, 31-34 (2017); published online 5 December 2016; corrected after print 12 January 2017

In the version of this article initially published, in Fig. $2 \mathrm{j}$, the percentage for the targets Mecp2, Nlgn3, and Drd1 should be $15.2 \%$, not $16.9 \%$; the same error appeared in the main text, next to last paragraph, "Our results show that $\sim 17 \%$..." should be "Our results show that $\sim 15 \%$...." In the Fig. 2 legend, KASH should be spelled out as "KASH, Klarsicht ANC1 Syne1 homology..." (not "KASH ANC1, Syne homology..."). The errors have been corrected in the HTML and PDF versions of the article.

\section{Erratum: The cancer bloodhounds}

\section{Sarah Webb}

Nat. Biotechnol. 34, 1090-1094 (2016); published online 8 November 2016; corrected after print 1 December 2016

In the version of this article initially published, in Table 1, "Blood-based digital sequencing of gene panel of 70 single base mutations..." should have read, "Blood-based digital sequencing of single-base mutations in 70 genes..." The errors have been corrected in the HTML and PDF versions of the article. 